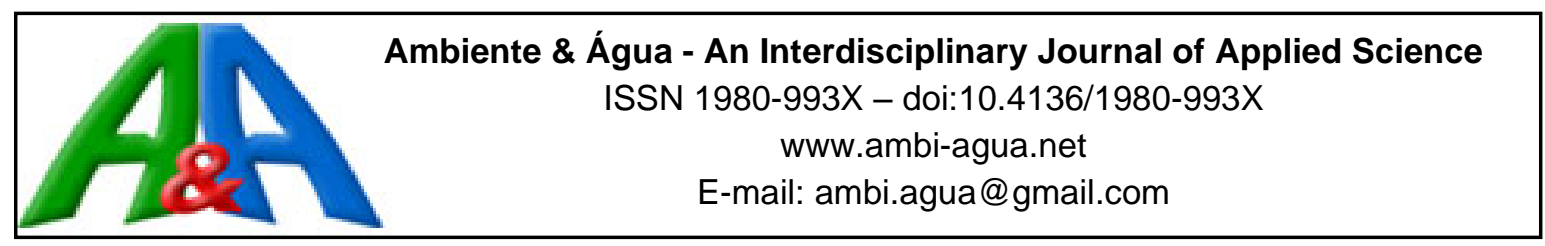

\title{
Nutrient-use efficiency of Eucalyptus genotypes grown in Luvisol
}

\author{
ARTICLES doi:10.4136/ambi-agua.2608
}

Received: 27 Jun. 2020; Accepted: 26 Feb. 2021

\author{
Kristiana Fiorentin dos Santos ${ }^{1 *}$; Túlio Barroso Queiroz ${ }^{2}$;

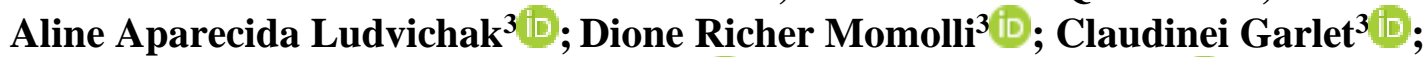 \\ Mauro Valdir Schumacher ${ }^{3}$; Elias Frank de Araújo 4 (D) \\ ${ }^{1}$ Departamento de Engenharia Florestal. Universidade Regional de Blumenau (FURB), Rua São Paulo, n 3250 , \\ CEP: 89030-000, Blumenau, SC, Brazil. \\ ${ }^{2}$ Bracell Bahia Florestal LTDA, Rua Doutor José Tiago Correia, nº 600, CEP: 48490-000, Alagoinhas, BA, \\ Brazil. E-mail: tulio-bq@ hotmail.com \\ ${ }^{3}$ Departamento de Engenharia Florestal. Universidade Federal de Santa Maria (UFSM), Avenida Roraima, \\ n 1000, CEP: 97105-900, Santa Maria, RS, Brazil. E-mail: aline_lud@yahoo.com.br, \\ dionemomolli@gmail.com, claudineigarlet@gmail.com, mvschumacher@gmail.com \\ ${ }^{4}$ Celulose Riograndense (CMPC), Rua São Geraldo, n 1680, CEP: 92703-470, Guaíba, RS, Brazil. \\ E-mail: elias.araujo@cmpcrs.com.br \\ *Corresponding author. E-mail: kristianafiorentin@gmail.com
}

\begin{abstract}
Superior productivity of genotypes in forest plantations depends on the supply, capture and use-efficiency of resources. In this context, knowledge regarding the nutritional efficiency of Eucalyptus influences farmers and researchers in decision-making and in the management of forest ecosystems. The aim of this research was to estimate nutrient-use efficiency in Eucalyptus genotypes planted in the state of Rio Grande do Sul, Brazil. We evaluated six potential genotypes at 43-month-old stands. Nutrient-use efficiency was calculated using the ratio of biomass and the amount of nutrients for each component of the biomass. Results here presented confirmed that there is synergism and antagonism between nutrients at the shoot level in the Eucalyptus genotypes. For stemwood, E. saligna showed the best utilization efficiency of N, P, K, S, and Mn; and E. urophylla $\times$ E. globulus for Mg, B, and Zn. Metabolic pathways control the production of biomass synthesized by each genotype and the differences between genotypes groups were on the basis of their nutrient-use efficiency in the biomass components. Stemwood was the component that showed the highest nutrient-use efficiency, while leaves presented the lowest nutrient-use efficiency. Additionally, our analyses identified how different each Eucalyptus genotype is and these traits may be used for clone allocation according to soil fertility.
\end{abstract}

Keywords: Eucalyptus clones, nutritional efficiency, sustainability.

\section{Eficiência de utilização de nutrientes de genótipos de Eucalyptus implantados em um Luvissolo}

\section{RESUMO}

A produtividade de genótipos superiores em plantações florestais está em função da oferta, captura e eficiência de uso dos recursos. Nesse contexto, o conhecimento sobre a eficiência nutricional do Eucalyptus influencia agricultores e pesquisadores na tomada de decisões e no manejo de ecossistemas florestais. A pesquisa teve como objetivo estimar a eficiência no uso 
de nutrientes em genótipos de Eucalyptus plantados no Estado do Rio Grande do Sul, Brasil. Foram avaliados seis genótipos potenciais e as avaliações foram realizadas em povoamentos de 43 meses de idade. A eficiência do uso de nutrientes foi calculada usando a razão de biomassa e a quantidade de nutrientes para cada componente da biomassa. Os resultados aqui apresentados confirmam que existe sinergismo e antagonismo entre os nutrientes no nível da parte aérea nos genótipos de Eucalyptus. Para a madeira do fuste, E. saligna apresentou a melhor eficiência de utilização de N, P, K, S e Mn; e E. urophylla $\times$ E. globulus para Mg, B e $\mathrm{Zn}$. As vias metabólicas controlam a produção de biomassa sintetizada por cada genótipo e as diferenças entre os grupos de genótipos foram baseadas na eficiência do uso de nutrientes nos componentes da biomassa. A madeira do caule foi o componente que apresentou maior eficiência de uso de nutrientes, enquanto as folhas apresentaram a menor eficiência de uso de nutrientes. Mas, além disso, nossas análises identificaram o quão diferente é cada genótipo de Eucalyptus e essas características podem ser usadas para alocação de clones de acordo com a fertilidade do solo.

Palavras-chave: clones de Eucalyptus, eficiência nutricional, sustentabilidade.

\section{INTRODUCTION}

The wide range of Eucalyptus species and hybrids, their suitability to different climatic and edaphic conditions, and their ease of propagation by seeds and cloning allowed the adaptation of this genus to various tropical and subtropical regions in Brazil (Queiroz et al., 2020). The possibility of using Eucalyptus wood for a range of purposes has led to large and small enterprises to establish Eucalyptus forests for multiple uses (Gonçalves et al., 2013). However, the rapid growth of these forests imposes high demand on soil resources, which is reflected in their water-carrying capacity, sustainability and nutrient-use efficiency (NUE) (Bellote et al., 2008).

Recently, Eucalyptus selection programs in Brazil started to consider NUE as a criterion for choosing superior genotypes, in addition to productivity, wood quality, tree shape, and disease resistance (Camargo et al., 2004). In this context, information about the mechanisms involved in the adaptive capacity of genotypes of interest, especially in conditions of low soil fertility, can guide the agriculture (Abenavoli et al., 2016) and the forestry sectors (Batista $e t$ al., 2015) to select those genotypes that can efficiently utilize existing nutrients in the soil or to improve the soil via fertilization (Batista et al., 2015).

Optimum NUE and nutrient cycling can be achieved through the use of management techniques that conserve crop residues as much as possible on the site by carrying out the least possible anthropic interventions and by analyzing which growth cycle is long enough to allow such cycling (Santana et al., 2002). Planting forests with superior genotypes in relation to nutritional efficiency can guarantee the sustainability of forest production (Batista et al., 2015) and the continuous success of future plantations will depend on the ability of forest managers to obtain high productivity of quality wood in an environmentally and sustainable manner (Gonçalves et al., 2013). The objective of the present study was to estimate the NUE of six genotypes of Eucalyptus in Rio Grande do Sul and also to recommend them according to nutritional status.

\section{MATERIALS AND METHODS}

The research was carried out in an experimental area belonging to the Celulose Riograndense Company (CMPC) in Horto Florestal Batovi, in the municipality of São Gabriel, Rio Grande do Sul, Brazil. The area is located under the geographical coordinates of $30^{\circ} 26^{\prime} 51.68^{\prime \prime} \mathrm{S}, 54^{\circ} 32^{\prime} 25.89^{\prime \prime} \mathrm{W}$. The climate, according to the Köppen climate classification, is characterized as humid subtropical (Cfa). The average annual temperature is approximately 
$18-20^{\circ} \mathrm{C}$ and the average annual precipitation reaches $1,600 \mathrm{~mm}$ (Alvares et al., 2013).

Planting was initiated in November 2012, with a spacing of $3.50 \mathrm{~m} \times 2.14 \mathrm{~m}$. The following Eucalyptus clones were planted: E. benthamii (P1), E. benthamii (P2), E. saligna, E. dunnii, hybrid of E. urophylla $\times$ E. globulus (E. uroglobulus), and hybrid of E. urophylla $\times$ E. grandis (E. urograndis). Eucalyptus benthamii (P1) is a provenance originating from Guarapuava, Paraná, Brazil and E. benthamii (P2) is from Telêmaco Borba, Paraná, Brazil. At the time of data collection, the stands were 43 months old. The soil of the experimental area is of the typical Luvisol haptic optic type. Physical and chemical attributes of the soil at depths of $0-60 \mathrm{~cm}$ are shown in Table 1.

For implantation of forest population, liming was performed using $2 \mathrm{Mg} \mathrm{ha}^{-1}$ of limestone, subsoiling down to $50 \mathrm{~cm}$ was performed, and ridges of $40 \mathrm{~cm}$ high were set up. During planting, $200 \mathrm{~kg} \mathrm{ha}^{-1}$ of single superphosphate was applied to the groove at a rate of $100 \mathrm{~g} \mathrm{plant}^{-1}$ in the form of $\mathrm{N}-\mathrm{P}_{2} \mathrm{O}_{5}-\mathrm{K}_{2} \mathrm{O}(06: 30: 06)+\mathrm{Zn}$ on the occasion of planting. Subsequently, two post-planting fertilizations were performed at six and twelve months in the form of $150 \mathrm{~kg} \mathrm{ha}{ }^{-1}$ of $\mathrm{N}-\mathrm{P}_{2} \mathrm{O}_{5}-\mathrm{K}_{2} \mathrm{O}(12: 00: 20)+0.5 \% \mathrm{~B}$ and $150 \mathrm{~kg}^{-1}$ of $\mathrm{N}-\mathrm{P}_{2} \mathrm{O}_{5}-\mathrm{K}_{2} \mathrm{O}$ (24:00:26), respectively. The following cultural practices were also performed: chemical weeding, prior to planting in a total area of $2.5 \mathrm{~kg} \mathrm{ha}^{-1}$ Scout (glyphosate), pre-emergent Oxyfluorfen $\left(3.5 \mathrm{~L} \mathrm{ha}^{-1}\right)$ treatment at 10 days after planting, and hand weeding and chemical weeding using $1.7 \mathrm{~kg} \mathrm{ha}^{-1}$ of Scout (glyphosate) at 4 and 9 months after planting.

For each genotype, a plot of $599.2 \mathrm{~m}^{2}$ was demarcated, where the DBH (diameter at breast height, measured at $1.30 \mathrm{~m}$ above ground level) and the heights were measured. Based on the data obtained in the plot inventory, three trees were sampled for each genotype. The selected trees were felled and separated into the components of leaves, branches, stembark and stemwood. All biomass samples were weighed in the field with a precision scale and packed in paper bags. Subsequently, they were sent to the laboratory and dried in an oven at $70^{\circ} \mathrm{C}$ to determine the moisture content. Based on the dry biomass of each component and the number of trees per hectare of each genotype, the total biomass per hectare was estimated (Table 2).

For the determination of nutrients, the samples were ground and subsequently subjected to chemical analysis to determine macronutrient $(\mathrm{N}, \mathrm{P}, \mathrm{K}, \mathrm{Ca}, \mathrm{Mg}$, and $\mathrm{S})$ and micronutrients $(\mathrm{B}$, $\mathrm{Cu}, \mathrm{Fe}, \mathrm{Mn}$, and $\mathrm{Zn}$ ) concentrations according to the methodology of Tedesco et al. (1995) and Miyazawa et al. (1999). The estimates of the nutrient stock for each component was obtained by multiplying the dried biomass by the concentration of nutrients. The estimate per hectare was performed by extrapolating the stock per individual based on the number of individuals present in each sampling unit (Table 3). The values of nutrient utilization efficiency (NUE) were obtained according to a calculation proposed by Barros et al (1986) (Equation 1) using the relationship between the amount of dry biomass of each component and the amount of nutrients stored in the respective biomass.

$N U E=\frac{(\text { Quantity of biomass })}{(\text { Quantity of nutrient })}$

For analysis of our data, we used the free software R Project (R Core Team, 2014). Data corresponding to the amount of nutrients in the biomass components of Eucalyptus genotypes (four repetitions) subjected to the same culture conditions were analyzed. These data were subjected to Pearson's correlation analyses using the 'color' function of the 'stats' package. In addition, a heatmap was used to visualize hierarchical clustering that ordered similar groups to amount of nutrients in the biomass components (leaves, branches, stembark and stemwood) taken from the UPGMA (Unweighted Pair Grouping with Arithmetic Mean) by means of the 'heatmaply' function. 
Table 1. Clay and chemical attributes of the soil of the area implanted area with different genotypes Eucalyptus at 43-monthold in São Gabriel, RS, Brazil.

\begin{tabular}{|c|c|c|c|c|c|c|c|c|c|c|c|}
\hline \multirow{2}{*}{ Depth } & Coarse sand & Fine sand & Silt & Clay & D.F & $\mathrm{V}$ & $\mathrm{m}$ & O.C & $\mathrm{pH}$ & $\mathrm{T}$ & $\mathrm{Al}$ \\
\hline & $2-0.02 \mathrm{~mm}$ & $0.2-0.05 \mathrm{~mm}$ & $0.05-0.002 \mathrm{~mm}$ & $<0.002$ & \multicolumn{4}{|c|}{$\%$} & $\mathrm{H}_{2} \mathrm{O}$ & \multicolumn{2}{|c|}{$\mathrm{cmol}_{\mathrm{c}} \mathrm{dm}^{-3}$} \\
\hline $0-40$ & 9.3 & 14.8 & 57.0 & 19.0 & 82 & 53 & 24 & 1.65 & 5.0 & 10.5 & 1.7 \\
\hline $40-60$ & 9.9 & 5.8 & 43.6 & 40.8 & 48 & 65 & 26 & 0.94 & 5.3 & 21.6 & 4.3 \\
\hline $60-85$ & 4.3 & 3.5 & 73.8 & 18.5 & 25 & 89 & 5 & 0.51 & 5.8 & 28.9 & 1.0 \\
\hline $85-110+$ & 6.0 & 4.8 & 84.5 & 4.7 & 21 & 96 & 0 & 0.17 & 6.8 & 29.9 & 0.0 \\
\hline \multirow{2}{*}{ Depth } & $\mathrm{N}$ & $\mathrm{P}$ & $\mathrm{K}$ & $\mathrm{Ca}$ & $\mathrm{Mg}$ & $\mathrm{S}$ & B & $\mathrm{Zn}$ & $\mathrm{Mn}$ & $\mathrm{Cu}$ & $\mathrm{Fe}$ \\
\hline & $\%$ & $\mathrm{mg} \mathrm{g}^{-1}$ & \multicolumn{3}{|c|}{$\mathrm{cmol}_{\mathrm{c}} \mathrm{dm}^{-3}$} & \multicolumn{5}{|c|}{$\mathrm{mg} \mathrm{dm}^{-3}$} & $\mathrm{~g} \mathrm{dm}^{3}$ \\
\hline $0-40$ & 0.15 & 3.7 & 0.06 & 3.7 & 1.5 & 13.1 & 0.5 & 0.6 & 4.0 & 1.2 & 0.2 \\
\hline $40-60$ & 0.11 & 2.0 & 0.16 & 10.3 & 3.3 & 9.8 & 0.5 & 0.5 & 2.0 & 1.2 & 0.1 \\
\hline $60-85$ & 0.07 & 1.5 & 0.23 & 17.7 & 6.0 & 8.9 & 0.5 & 0.5 & 4.0 & 1.0 & 0.1 \\
\hline $85-110+$ & 0.03 & 1.2 & 0.18 & 20.3 & 6.1 & 6.4 & 0.3 & 0.3 & 4.0 & 0.5 & 0.1 \\
\hline
\end{tabular}

D.F: Degree flocculation; V: base saturation; m: saturation by aluminum; O.C: organic carbon; $\mathrm{pH}_{\text {in }} \mathrm{H}_{2} \mathrm{O}$ (1:1); T: $\mathrm{pH}$ cation exchange capacity.

Table 2. Production and partition of biomass for the different components of genotypes Eucalyptus at 43 months old, established in São Gabriel, Rio Grande do Sul, Brazil.

\begin{tabular}{cccccc}
\hline \multirow{2}{*}{ Genotypes } & Leaves & Branches & Stembark & Stemwood & Total \\
\cline { 2 - 6 } & \multicolumn{5}{c}{ Mg ha $^{-1}$} \\
\hline E. benthamii $(\mathrm{P} 1)$ & $6.09 \mathrm{c}$ & $10.16 \mathrm{c}$ & $5.93 \mathrm{a}$ & $33.16 \mathrm{c}$ & $55.34 \mathrm{c}$ \\
E. benthamii $(\mathrm{P} 2)$ & $3.70 \mathrm{~d}$ & $6.12 \mathrm{e}$ & $4.42 \mathrm{~b}$ & $33.60 \mathrm{c}$ & $47.84 \mathrm{c}$ \\
E. saligna & $5.85 \mathrm{c}$ & $12.70 \mathrm{~b}$ & $6.19 \mathrm{a}$ & $43.58 \mathrm{~b}$ & $68.32 \mathrm{~b}$ \\
E. dunnii & $2.85 \mathrm{~d}$ & $8.26 \mathrm{~d}$ & $3.76 \mathrm{~b}$ & $18.81 \mathrm{~d}$ & $33.68 \mathrm{~d}$ \\
E. uroglobulus & $10.39 \mathrm{a}$ & $11.53 \mathrm{~b}$ & $6.72 \mathrm{a}$ & $55.36 \mathrm{a}$ & $84.00 \mathrm{a}$ \\
E. urograndis & $9.04 \mathrm{~b}$ & $20.75 \mathrm{a}$ & $6.67 \mathrm{a}$ & $44.33 \mathrm{~b}$ & $80.79 \mathrm{a}$ \\
\hline
\end{tabular}

Averages of each component of biomass in different treatments (genotypes) followed by equal letters, do not differ significantly by the Tukey test at the $5 \%$ level of error. Source: Santos et al. (2019). 
Table 3. Amount of nutrients in the biomass components of different genotypes of Eucalyptus at 43 months old, established in São Gabriel, Rio Grande do Sul, Brazil.

\begin{tabular}{|c|c|c|c|c|c|c|c|c|c|c|c|c|}
\hline \multirow{2}{*}{ Genotypes } & \multirow{2}{*}{ Components } & $\mathrm{N}$ & $\mathrm{P}$ & $\mathrm{K}$ & $\mathrm{Ca}$ & $\mathrm{Mg}$ & $\mathrm{S}$ & B & $\mathrm{Cu}$ & $\mathrm{Fe}$ & Mn & $\mathrm{Zn}$ \\
\hline & & \multicolumn{6}{|c|}{$\mathrm{kg} \mathrm{ha}^{-1}$} & \multicolumn{5}{|c|}{$\mathrm{g} \mathrm{ha}^{-1}$} \\
\hline \multirow{4}{*}{ E. benthamii (P1) } & Leaves & 110.29 & 6.36 & 36.30 & 69.09 & 16.89 & 9.51 & 232.91 & 34.96 & 807.86 & 7246.14 & 72.86 \\
\hline & Branches & 20.17 & 1.39 & 19.27 & 103.17 & 17.40 & 2.89 & 103.52 & 37.84 & 633.15 & 7724.68 & 89.40 \\
\hline & Stembark & 23.99 & 2.43 & 24.72 & 83.85 & 18.51 & 2.55 & 93.01 & 15.10 & 269.57 & 6619.54 & 65.78 \\
\hline & Stemwood & 52.27 & 5.08 & 64.61 & 38.78 & 16.14 & 6.60 & 185.40 & 26.61 & 938.24 & 5893.36 & 191.70 \\
\hline \multirow{4}{*}{ E. benthamii (P2) } & Leaves & 78.82 & 4.28 & 22.31 & 22.41 & 8.85 & 4.56 & 97.25 & 26.29 & 393.68 & 3568.63 & 48.04 \\
\hline & Branches & 18.48 & 1.38 & 15.27 & 29.67 & 5.18 & 1.46 & 71.64 & 26.45 & 192.24 & 3902.22 & 46.94 \\
\hline & Stembark & 18.01 & 2.18 & 16.62 & 46.40 & 14.50 & 1.68 & 92.13 & 15.54 & 117.35 & 4793.05 & 52.87 \\
\hline & Stemwood & 50.34 & 5.34 & 60.06 & 17.06 & 7.48 & 4.68 & 128.72 & 66.64 & 552.20 & 3707.66 & 242.54 \\
\hline \multirow{4}{*}{ E. saligna } & Leaves & 92.87 & 4.66 & 37.16 & 63.83 & 18.18 & 5.11 & 175.35 & 31.89 & 567.13 & 4657.27 & 62.03 \\
\hline & Branches & 20.71 & 1.13 & 23.35 & 133.81 & 25.39 & 2.80 & 148.13 & 61.46 & 1032.35 & 8514.80 & 132.11 \\
\hline & Stembark & 28.28 & 1.53 & 15.48 & 68.17 & 22.67 & 1.79 & 98.11 & 14.18 & 225.10 & 6032.84 & 35.32 \\
\hline & Stemwood & 51.29 & 3.64 & 59.05 & 36.77 & 21.69 & 5.31 & 240.94 & 69.78 & 1765.68 & 3309.26 & 307.66 \\
\hline \multirow{4}{*}{ E. dunnii } & Leaves & 49.58 & 2.60 & 16.05 & 30.42 & 9.31 & 3.00 & 75.49 & 23.37 & 457.13 & 2802.39 & 26.87 \\
\hline & Branches & 19.40 & 1.43 & 28.60 & 72.05 & 14.85 & 2.17 & 117.45 & 39.06 & 543.18 & 5873.21 & 66.11 \\
\hline & Stembark & 9.82 & 1.49 & 24.32 & 34.85 & 10.88 & 0.93 & 69.71 & 5.17 & 194.45 & 3308.41 & 26.86 \\
\hline & Stemwood & 26.92 & 2.72 & 41.61 & 28.23 & 17.87 & 3.61 & 111.26 & 38.79 & 323.09 & 2884.73 & 74.93 \\
\hline \multirow{4}{*}{ E. uroglobulus } & Leaves & 133.34 & 7.59 & 48.76 & 83.30 & 14.54 & 8.46 & 250.35 & 45.93 & 623.97 & 9884.07 & 84.10 \\
\hline & Branches & 18.19 & 1.52 & 27.98 & 74.96 & 6.75 & 2.75 & 127.94 & 40.39 & 430.87 & 6556.34 & 52.94 \\
\hline & Stembark & 22.61 & 2.96 & 32.25 & 60.29 & 18.63 & 1.95 & 125.44 & 16.35 & 325.35 & 6195.22 & 42.41 \\
\hline & Stemwood & 71.89 & 5.32 & 100.21 & 30.90 & 11.24 & 9.94 & 168.88 & 102.30 & 1013.28 & 5126.07 & 171.83 \\
\hline \multirow{4}{*}{ E. urograndis } & Leaves & 142.99 & 8.03 & 59.01 & 117.18 & 21.60 & 7.76 & 387.63 & 64.75 & 1026.00 & 7967.63 & 109.80 \\
\hline & Branches & 32.43 & 3.38 & 44.77 & 222.54 & 38.96 & 4.52 & 234.21 & 102.64 & 1777.39 & 15634.53 & 173.32 \\
\hline & Stembark & 21.70 & 2.49 & 24.23 & 80.53 & 23.61 & 1.61 & 97.86 & 15.35 & 244.60 & 6526.83 & 51.82 \\
\hline & Stemwood & 64.32 & 6.40 & 91.76 & 36.14 & 22.92 & 8.04 & 231.87 & 105.97 & 966.68 & 5086.16 & 240.82 \\
\hline
\end{tabular}




\section{RESULTS AND DISCUSSION}

Results presented here confirmed that there is synergism and antagonism between nutrients at the shoot level in the Eucalyptus genotypes in a Luvisol. Figure 1 shows the correlation for the amount of essential plant nutrients (macronutrients $\mathrm{N}, \mathrm{P}, \mathrm{K}, \mathrm{Ca}, \mathrm{Mg}$, and $\mathrm{S}$ and micronutrients $\mathrm{Fe}, \mathrm{B}, \mathrm{Mn}, \mathrm{Zn}$ and $\mathrm{Cu}$ ) of genotypes of Eucalyptus implanted in Luvisol; blue and red lines are positive and negative correlations, respectively, and their correlation intensity is expressed by the thickness of the line that connects each nutrient. The efficiency of mineral elements in plants is determined by the amount of nutrients in plant tissues so it is an answer to metabolism and characteristics of the electrophysics of plants (Shabala, 2006).

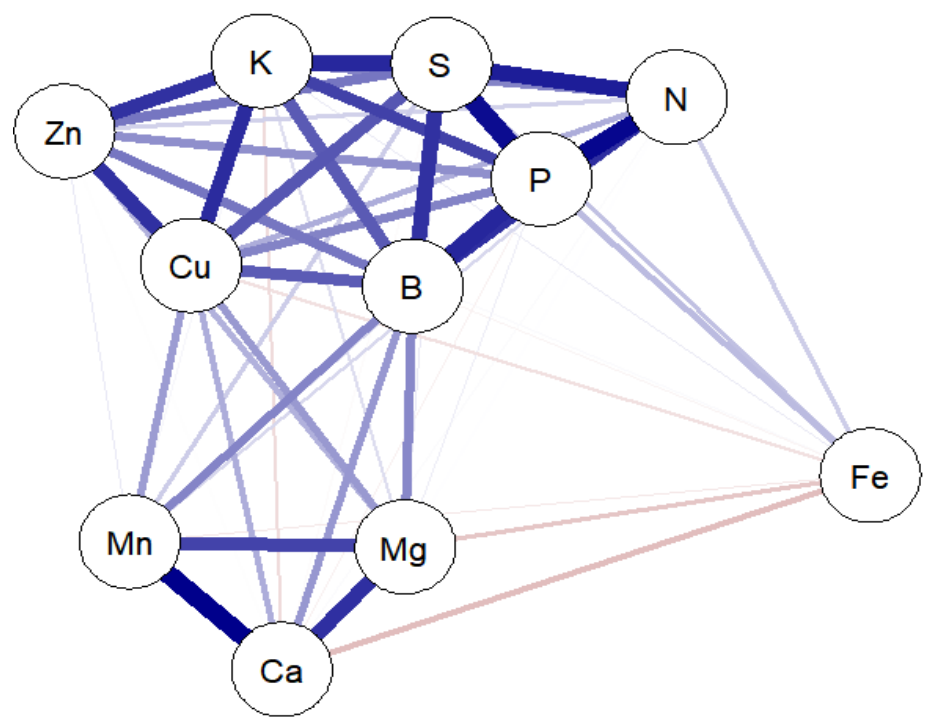

Figure 1. Diagram of Pearson's correlation coefficients matrix among nutrients of the analyzed Eucalyptus genotypes in a Luvisol (see Table 5 Supplementary material).

Manganese (Mn) and calcium (Ca) are strongly (> 0.9) associated in Eucalyptus genotypes implanted in a Luvisol. This is supported by metal transport from the cytosol to the vacuole antiporter CAX2 (calcium exchanger 2) due to expression from isolated root tonoplast vesicles (Wu et al., 2003; Pii et al., 2015). Therefore, some heterologous species improve Mn tolerance via its accumulation within plant tissues (Hirschi et al., 2000).

Despite iron $(\mathrm{Fe})$ being essential to plant development, it shows weak correlation with other nutrients. It makes part of the enzyme composition in peroxidase, cytochrome oxidase, leghemoglobin and ferredoxin and also it participates in photosynthesis processes, respiration, nitrogen fixation, hormone synthesis and electron transfer (Layer et al., 2010; Krohling et al., 2016). For most macronutrients, the mutual interactions on yield levels are synergistic, whereas divalent cations show antagonistic effects on yield (Rietra et al., 2017). Therefore, interaction between elements can yield antagonistic or synergistic works to nutrient-use efficiency.

The NUE represents how many units of biomass are formed per unit of nutrient; that is, the higher the value of NUE the more efficient is the conversion of nutrients into biomass (Schumacher et al., 2019). Results obtained from this study showed that besides $\mathrm{P}$ and $\mathrm{K}$ in $E$. benthamii (P1) (branches), Fe and $\mathrm{Zn}$ in E. saligna (stembark), and $\mathrm{Cu}$ in $E$. dunnii and $E$. urograndis (stembark), stemwood was the component that presented the highest NUE values for the analyzed elements (Table 4). This is a very important fact in forestry because stemwood is the main product taken from the stands. According to Reis and Barros (1990), NUE in the production of wood varies with type of soil (availability of nutrients), population of plants, and plant species. 
Table 4. Nutrient-use efficiency in the biomass components of different genotypes of Eucalyptus at 43 months old, established in São Gabriel, Rio Grande do Sul, Brazil.

\begin{tabular}{|c|c|c|c|c|c|c|c|c|c|c|c|c|}
\hline Genotype & Component & $\mathrm{N}$ & $\mathrm{P}$ & $\mathrm{K}$ & $\mathrm{Ca}$ & $\mathrm{Mg}$ & S & B & $\mathrm{Cu}$ & $\mathrm{Fe}$ & $\mathrm{Mn}$ & $\mathrm{Zn}$ \\
\hline \multirow{4}{*}{ E. benthamii $(\mathrm{P} 1)$} & Leaves & 55 & 958 & 168 & 88 & 361 & 641 & 26,161 & 174,265 & 7,542 & 841 & 83,624 \\
\hline & Branches & 504 & 7,315 & 527 & 98 & 584 & 3,514 & 98,124 & 268,425 & 16,043 & 1,315 & 113,629 \\
\hline & Stembark & 247 & 2,437 & 240 & 71 & 320 & 2,325 & 63,766 & 392,642 & 22,001 & 896 & 90,159 \\
\hline & Stemwood & 634 & 6,527 & 513 & 855 & 2,054 & 5,023 & 178,834 & $1,245,970$ & 35,339 & 5,626 & 172,958 \\
\hline \multirow{4}{*}{ E. benthamii $(\mathrm{P} 2)$} & Leaves & 47 & 865 & 166 & 165 & 418 & 811 & 38,045 & 140,720 & 9,398 & 1,037 & 77,015 \\
\hline & Branches & 331 & 4,432 & 401 & 206 & 1,181 & 4,198 & 85,456 & 231,500 & 31,847 & 1,569 & 130,416 \\
\hline & Stembark & 245 & 2,030 & 266 & 95 & 305 & 2,625 & 47,951 & 284,259 & 37,646 & 922 & 83,556 \\
\hline & Stemwood & 668 & 6,289 & 559 & 1,970 & 4,490 & 7,174 & 261,043 & 504,225 & 60,852 & 9,063 & 138,542 \\
\hline \multirow{4}{*}{ E. saligna } & Leaves & 63 & 1,254 & 157 & 92 & 322 & 1,143 & 33,348 & 183,344 & 10,311 & 1,256 & 94,274 \\
\hline & Branches & 613 & 11,234 & 544 & 95 & 500 & 4,538 & 85,720 & 206,606 & 12,299 & 1,491 & 96,113 \\
\hline & Stembark & 219 & 4,051 & 400 & 91 & 273 & 3,461 & 63,113 & 436,773 & 27,508 & 1,026 & 175,298 \\
\hline & Stemwood & 850 & 11,988 & 738 & 1,185 & 2,009 & 8,213 & 180,876 & 624,557 & 24,682 & 13,169 & 141,650 \\
\hline \multirow{4}{*}{ E. dunnii } & Leaves & 57 & 1,098 & 178 & 94 & 306 & 949 & 37,733 & 121,883 & 6,231 & 1,016 & 106,014 \\
\hline & Branches & 426 & 5,768 & 289 & 115 & 556 & 3,810 & 70,318 & 211,441 & 15,205 & 1,406 & 124,926 \\
\hline & Stembark & 383 & 2,525 & 154 & 108 & 345 & 4,056 & 53,887 & 726,610 & 19,318 & 1,135 & 139,869 \\
\hline & Stemwood & 699 & 6,912 & 452 & 666 & 1,053 & 5,211 & 169,089 & 485,008 & 58,229 & 6,522 & 251,069 \\
\hline \multirow{4}{*}{ E. uroglobulus } & Leaves & 78 & 1,369 & 213 & 125 & 715 & 1,229 & 41,518 & 226,306 & 16,658 & 1,052 & 123,592 \\
\hline & Branches & 634 & 7,609 & 412 & 154 & 1,708 & 4,199 & 90,116 & 285,483 & 26,759 & 1,759 & 217,794 \\
\hline & Stembark & 297 & 2,273 & 208 & 111 & 361 & 3,445 & 53,552 & 410,851 & 20,647 & 1,084 & 158,378 \\
\hline & Stemwood & 770 & 10,401 & 552 & 1,791 & 4,927 & 5,571 & 327,797 & 541,126 & 54,633 & 10,799 & 322,165 \\
\hline \multirow{4}{*}{ E. urograndis } & Leaves & 63 & 1,125 & 153 & 77 & 418 & 1,165 & 23,319 & 139,607 & 8,810 & 1,134 & 82,325 \\
\hline & Branches & 640 & 6,131 & 464 & 93 & 533 & 4,594 & 88,601 & 202,164 & 11,675 & 1,327 & 119,725 \\
\hline & Stembark & 307 & 2,681 & 275 & 83 & 282 & 4,131 & 68,119 & 434,381 & 27,254 & 1,021 & 128,658 \\
\hline & Stemwood & 689 & 6,927 & 483 & 1,227 & 1,934 & 5,512 & 191,179 & 418,304 & 45,857 & 8,716 & 184,073 \\
\hline
\end{tabular}


In Luvisol, for the different species, the lowest NUE elements were observed for $\mathrm{Ca}, \mathrm{Mg}$ and $\mathrm{Mn}$ (E. benthamii (P2) and E. saligna); K, Ca and $\mathrm{Mg}$ (E. uroglobulus); $\mathrm{Ca}$ and $\mathrm{Mg}$ (E. benthamii $(\mathrm{P} 1)$; $\mathrm{Mg}$ and $\mathrm{Mn}$ (E. urograndis); and $\mathrm{K}$ (E. dunnii) obtained from stembark. In general, the results confirm the hypothesis that the NUE of the leaves would be very similar for genotypes. There is a broad consensus that the concentration of nutrients in Eucalyptus genus follows the order of leaves > bark > branches > wood (Resquin et al., 2020). Although wood nutrients are a smaller fraction, they are important in the nutrient cycling and in the balance of nutrients for the Eucalyptus stand (especially for P, S, B, Cu, Fe and Zn). In the same context, if wood with bark is harvested, $\mathrm{Ca}$ and $\mathrm{Mg}$ nutrients may greatly limit the productivity of the next cycle; however this limitation may be reduced if only the wood is harvested. According to Reis and Barros (1990), the allocation of nutrients in the bark is of great importance in choosing the type of exploitation to be adopted, that is, whether the stem should be exploited or only wood.

Results also revealed that micronutrients showed the best NUE, with $\mathrm{Cu}$ being the most prominent in all components, presenting the highest values for stemwood, with the exception of E. dunnii, where the highest value was found for stembark. The micronutrient with the lowest NUE value for all the components was Mn. NUE of the micronutrients in stemwood followed this order: $\mathrm{Cu}>\mathrm{B}>\mathrm{Zn}>\mathrm{Fe}>\mathrm{Mn}$, with the exception of $E$. dunnii, where the value of $\mathrm{Zn}$ was higher than that of B. This same trend for most genotypes was reported by Ludvichak (2016) for a 9-year-old hybrid of E. urograndis in Pinheiro Machado, RS, Brazil. Viera et al. (2015) evaluated a hybrid population of E. urophylla $\times$ E. globulus of 10 years in Eldorado do Sul, RS, Brazil and also reported the same trend.

Among the macronutrients, $\mathrm{P}$ showed the highest conversion rate for stemwood in all genotypes, except in E. benthamii (P2) where the highest NUE value was found in S. In contrast, $\mathrm{K}$ presented the lowest conversion rate. Besides $E$. benthamii (P2), which had superior $\mathrm{S}$ to $\mathrm{P}$, and E. dunnii, which had superior $\mathrm{N}$ to $\mathrm{Ca}$, the NUE of stemwood decreased in this order: $\mathrm{P}>$ $\mathrm{S}>\mathrm{Mg}>\mathrm{Ca}>\mathrm{N}>\mathrm{K}$.

This same trend was reported by Ludvichak (2016) and Viera et al. (2015). Schumacher et al. (2019), on the other hand, studied Eucalyptus spp. stands in small farms located in Rio Grande do Sul state, Brazil, and reported a trend different from the one found in this study (P > $\mathrm{S}>\mathrm{Mg}>\mathrm{K}>\mathrm{N}>\mathrm{Ca}$ ). According to Santana et al. (2002), variation in NUE could occur due to several factors, such as the intrinsic characteristics of the genetic material, failure to obtain the optimal or critical nutritional balance between soil plant and all nutrients (that is, there may have been a limitation of one or more available nutrients), and water relations.

For stemwood, E. saligna had the highest NUE of N, P, K, S and Mn; E. uroglobulus had the highest NUE of Mg, B and Zn; and E. benthamii (P2) had the highest NUE of Ca and Fe. The NUE of $\mathrm{P}$ in E. saligna was 46 and $48 \%$ higher than that in clones E. benthamii (P1) and E. benthamii (P2), respectively. The NUE of K in E. Saligna was 35 and $39 \%$ higher than that in E. urograndis and E. dunnii, respectively. According to Caldeira et al. (2002), the evaluation of NUE in different forest species, their origins, and/or clones is important to a forester as it helps in choosing the genotype to be used for reforestation. However, it is important to note that it is difficult to select a genotype that has a high NUE of all the essential elements (Camargo et al., 2004). Therefore, forest managers should use genetic materials with high NUE that is compatible with the fertility of the soils because if materials with high NUEs are planted in low fertility soils that do not receive fertilization, soil depletion would occur rapidly (Santana et al., 2002).

To select genotypes, the breeder needs to use information about NUE and variation in the shoot-nutrient content. The analysis of the dependence of the efficiency of accumulation of a number of basic micro- and macronutrients made it possible to identify its dependence in the biomass components of different genotypes of Eucalyptus. Heatmap is a wrapper accompanied 
by dendrograms for visualizing observations correlations through color (Figure 2). Trends of nutrients ( $\mathrm{N}, \mathrm{P}, \mathrm{K}, \mathrm{Ca}, \mathrm{Mg}, \mathrm{S}, \mathrm{B}, \mathrm{Cu}, \mathrm{Fe}, \mathrm{Mn}$ and $\mathrm{Zn}$ ) can be readily assessed from a heatmap depiction. In this figure, yellow is a positive correlation and blue is a negative correlation. The rows and columns of the matrix are ordered to highlight patterns of Eucalyptus genotypes and the amount of nutrients per dry biomass in the tree components so heatmap clustering comprises the nutrient-use efficiency.

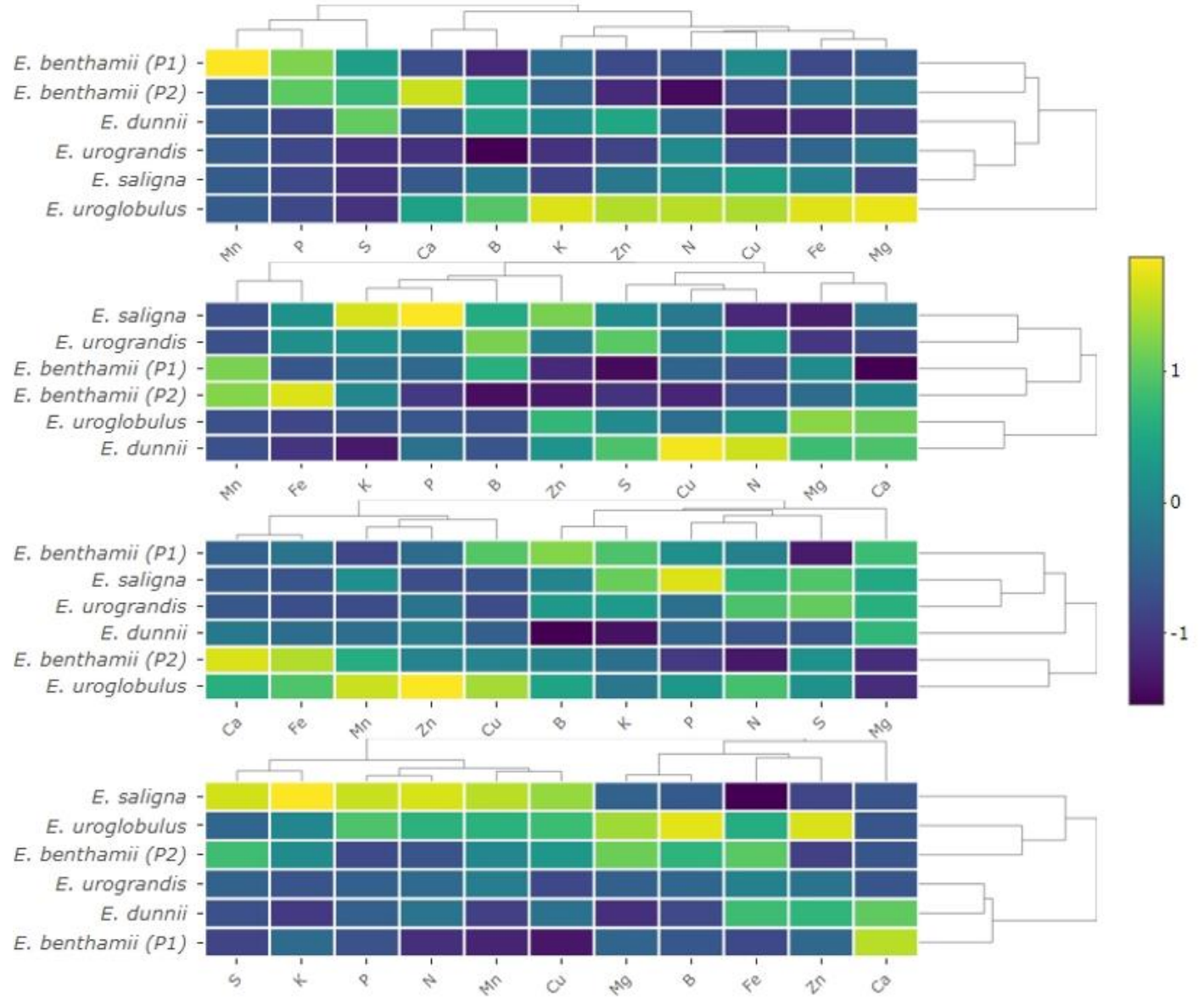

Figure 2. Heatmap used for visualizing data of Pearson's correlation coefficients matrix of nutrientuse efficiency in the biomass components (A - leaves; B - stembark; C - branches and D - stemwood) of different Eucalyptus genotypes implanted in a Luvisol.

The characteristics of soil type and lower excited electron states of chlorophyll, carotenoids, chromophores of the phytochromic and cryptochromic system provides to intraand intermolecular charge separation reactions and thereby generates polarization and mechanism of transport to the nutrients for each biomass component in the plants (Kholmanskiy et al., 2019). Eucalyptus uroglobulus and E. dunni genotypes differ much in their nutrient utilization efficiency under field conditions because of the capacity for the absorption, translocation and conversion of the nutrients into the biomass. Eucalyptus urogobulus showed the highest performance for stemwood biomass (55.36 $\left.\mathrm{Mg} \mathrm{ha}^{-1}\right)$. A negative correlation indicates that nutrient-use efficiency in the biomass components (leaves, stembark and stemwood) move in opposite directions, and that the relationship also becomes stronger the closer to minus 1 .

\section{CONCLUSIONS}

Interaction between elements can yield antagonistic or synergistic effects on nutrient-use efficiency and Eucalyptus genotypes differed in terms of nutritional efficiency and nutrient 
function according to biomass components. In general, stemwood is the biomass component that showed the highest efficiency in nutrient use. The leaf component showed the lowest efficiency.

Nutrient-use efficiency is dependent on genotype traits. Eucalyptus saligna had the highest NUE of N, P, K, S and Mn, and E. uroglobulus had the highest NUE of Mg, B and Zn. The data presented here could facilitate tree breeding by enhancing phenotypic analyses based on nutritional factors during the allocation process for specific site conditions.

\section{ACKNOWLEDGMENTS}

Celulose Riograndense - CMPC, for the logistical, technical and financial support to carry out this work.

\section{REFERENCES}

ABENAVOLI, R.; LONGOA, C.; LUPINA, A.; MILLER, A. J.; ARANITI, F.; MERCATI, F.; PRINCI, M. P.; SUNSERI, F. Phenotyping two tomato genotypes with different nitrogen use efficiency. Plant Physiology and Biochemistry, v. 107, p. 21-32, 2016. https://doi.org/10.1016/j.plaphy.2016.04.02

ALVARES, C. A.; STAPE, J. L.; SENTELHAS, P. C.; GONÇALVES, J. L. M.; SPAROVEK, G. Köppen's climate classification map for Brazil. Meteorologische Zeitschrift, v. 22, n. 6, p. 1-18, 2013. https://doi.org/10.1127/0941-2948/2013/0507

BARROS, N. F.; NOVAIS, R. F.; CARMO, D. N.; NEVES, J. C. L. Classificação nutricional de sítios florestais - descrição de uma metodologia. Revista Árvore, v. 10, p. 112-120, 1986.

BATISTA, R. O.; FURTINI NETO, A. E.; DECCETTI, S. F. C. Eficiência nutricional em clones de cedro-australiano. Scientia Forestalis, v. 43, n. 107, p. 647-655, 2015.

BELlOTE, A. F. J.; DEDECEK, R. A.; SILVA, H. D. Nutrientes minerais biomassa e deposição de serapilheira em plantio de Eucalyptus com diferentes sistemas de manejo de resíduos florestais. Pesquisa Florestal Brasileira, n. 56, p. 31-41, 2008.

CALDEIRA, M. V. W.; RONDON NETO, R. M.; SCHUMACHER, M. V. Avaliação da eficiência nutricional de três procedências australianas de Acácia-negra (Acacia mearnsii De Wild.). Revista Árvore, v. 26, n. 5, p. 615-620, 2002. https://doi.org/10.1590/S010067622002000500012

CAMARGO, M. L. P.; MORAES, C. B.; MORI, E. S.; GUERRINI, I. A.; MELLO, E. J.; ODA, S. Considerações sobre eficiência nutricional em Eucalyptus. Científica, v. 32, n. 2, p. 191-196, 2004. https://doi.org/10.15361/1984-5529.2004v32n2p191-196

GONÇALVES, J. L. M.; ALVARES, C. A.; HIGA, A. R.; SILVA, L. D.; ALFENAS, A. C.; STAHL, J.; FERRAZ, S. B.; LIMA, W. P.; BRANCALION, P. H. S.; HUBNER, A.; BOUILLET, J. P. D.; LACLAU, J. P.; NOUVELLON, Y.; EPRON, D. Integrating genetic and silvicultural strategies to minimize abiotic and biotic constraints in Brazilian eucalypt plantations. Forest Ecology and Management, v. 301, p. 6-27, 2013. https://doi.org/10.1016/j.foreco.2012.12.030

HIRSCHI, D.; KORENKOV, V. D.; WILGANOWSKI, N. L.; WAGNER, G. J. Expression of Arabidopsis CAX2 in Tobacco. Altered metal accumulation and increased manganese $\begin{array}{llllll}\text { tolerance. Plant Physiology, v. 124, p. } 2000 . & \text { 125-134, }\end{array}$ https://doi.org/10.1104/pp.124.1.125 
KHOLMANSKIY, A.; SMIRNOV, A.; SOKOLOV, A.; PROSHKIN, Y. Modeling of extraction elements by plants. Current Plant Biology, v. 19, p. 1-8. 2019. https://doi.org/10.1016/j.cpb.2019.100104

KROHLING, C. A.; EUTRÓPIO, F. J.; BERTOLAZI, A. A.; DOBBS, L. B.; CAMPOSTRINI, E.; DIAS, T.; RAMOS, A. C. Ecophysiology of iron homeostasis in plants. Soil Science $\begin{array}{lllllll}\text { and Plant } & \text { Nutrition, } & \text { v. } & \text { 62, } & \text { 39-47, }\end{array}$ https://doi.org/10.1080/00380768.2015.1123116

LAYER G.; REICHELT J.; JAHN D.; HEINZ D. W. Structure and function of enzymes in heme biosynthesis. Protein Science, v. 19, p. 1137-1161, 2010. https://doi.org/10.1002/pro.405

LUDVICHAK. A. A. Biomassa e nutrientes do híbrido Eucalyptus urograndis e Acacia mearnsii em plantios monoespecíficos e mistos. 2016. 71f. Dissertação (Mestrado em Engenharia Florestal) - Universidade Federal de Santa Maria, Santa Maria, 2016.

MIYAZAWA, M.; PAVAN, M. A.; MURAOKA, T. Análises químicas de tecido vegetal. In: SILVA, F. C. da (ed.). Manual de análises químicas de solos, plantas e fertilizantes. Brasília: Embrapa Comunicação para Transferência de Tecnologia, 1999. p. 171-224.

PII, Y.; CESCO, S.; MIMMO, T. Shoot ionome to predict the synergism and antagonism between nutrients as affected by substrate and physiological status. Plant Physiology and Biochemistry, v. 94, p. 48-56, 2015. https://doi.org/10.1016/j.plaphy.2015.05.002

QUEIROZ, T. B.; CAMPOE, O. C.; MONTES, C. R.; ALVARES, C. A.; CUARTAS, M. Z.; GUERRINI, I. A. Temperature thresholds for Eucalyptus genotypes growth across tropical and subtropical ranges in South America. Forest Ecology and Management, v. 472, n. 118248, p. 1-10, 2020. https://doi.org/10.1016/j.foreco.2020.118248

R CORE TEAM. R: A Language and Environment for Statistical Computing. Vienna, 2014.

REIS, M. G. F.; BARROS, N. F. Ciclagem de Nutrientes em Plantios de Eucalipto. In: BARROS, N. F.; NOVAIS, R. F. (ed.). Relação solo-eucalipto. Viçosa: Folha de Viçosa, 1990. p. 265-302.

RESQUIN, F.; NAVARRO-CERRILLO, R. M.; CARRASCO-LETELIE, L.; CASNATI, C. R.; BENTANCOR, L. Evaluation of the nutrient content in biomass of Eucalyptus species from short rotation plantations in Uruguay. Biomass and Bioenergy, v. 134, p. 1-14, 2020. https://doi.org/10.1016/j.biombioe.2020.105502

RIETRA, R. P. J. J.; HEINEN, M.; DIMKPA, C. O.; BINDRABAN, P. S. Effects of nutrient Antagonism and synergism on yield and fertilizer use efficiency. Communications in Soil and Plant Analysis, v. 48, n. 16, p. 1895-1920, 2017. https://doi.org/10.1080/00103624.2017.1407429

SANTANA, R. C.; BARROS, N. F.; NEVES, J. C. L. Eficiência de utilização de nutrientes e sustentabilidade da produção em procedências de Eucalyptus grandis e Eucalyptus saligna em sítios florestais do estado de São Paulo. Revista Árvore. v. 26. n. 4. p. $447-$ 457, 2002.

SANTOS, K. F.; LUDVICHAK, A. A.; QUEIROZ, T. B.; SCHUMACHER, M. V.; ARAÚJO, E. F. Biomass production and nutrient content in different Eucalyptus genotypes in Pampa Gaúcho, Brazil. Revista Brasileira de Ciências Agrárias, v. 14, n. 4, e6575, 2019. http://dx.doi.org/10.5039/agraria.v14i4a6575 
SCHUMACHER, M. V.; WITSCHORECK, R.; CALIL. F. N.; LOPES, V. G. Manejo da biomassa e sustentabilidade nutricional em povoamentos de Eucalyptus spp. em pequenas propriedades rurais. Ciência Florestal, v. 29, n. 1, p. 144-156, 2019. https://doi.org/10.5902/198050985135

SHABALA, S. Non-invasive microelectrode ion flux measurements in plant stress physiology. In: VOLKOV, A. G. (eds.). Plant Electrophysiology. Berlin: Springer, 2006.

TEDESCO, M. J.; GIANELlO, C.; BISSANI, C. A.; BOHNEN, H.; VOLKWEISS, S. J. Análise de solo, plantas e outros materiais. Porto Alegre: UFRGS; Departamento de Solo, 1995. 174p.

VIERA, M.; SCHUMACHER, M. V.; TRÜBY, P.; ARAÚJO, E. F. Implicações nutricionais com base em diferentes intensidades de colheita da biomassa de Eucalyptus urophylla $\mathrm{x}$ Eucalyptus globulus. Ciência Rural, v. 45, n. 3, p. 432-439, 2015. http://dx.doi.org/10.1590/0103-8478cr20120367

WU, C.; LI, X.; YUAN, W.; CHEN, G.; KILIAN, A.; LI, J.; XU, C.; LI, X.; ZHOU, D. X.; WANG, S.; ZHANG, Q. Development of enhancer trap lines for functional analysis of the rice genome. The plant journal, v. 35, p. 418-427, 2003. https://doi.org/10.1046/j.1365-313X.2003.01808

\section{Supplementary material}

Table 5. Correlation matrix used in the diagram of Pearson's correlation coefficients matrix among nutrients of the analyzed Eucalyptus genotypes implanted in a Luvisol.

\begin{tabular}{cccccccccccc}
\hline & $\mathrm{N}$ & $\mathrm{P}$ & $\mathrm{K}$ & $\mathrm{Ca}$ & $\mathrm{Mg}$ & $\mathrm{S}$ & $\mathrm{B}$ & $\mathrm{Cu}$ & $\mathrm{Fe}$ & $\mathrm{Mn}$ & $\mathrm{Zn}$ \\
\hline $\mathrm{N}$ & 1.00 & 0.91 & 0.45 & 0.01 & 0.00 & 0.82 & 0.77 & 0.30 & 0.18 & 0.15 & 0.17 \\
$\mathrm{P}$ & 0.91 & 1.00 & 0.70 & -0.05 & 0.06 & 0.89 & 0.79 & 0.45 & 0.25 & 0.15 & 0.41 \\
$\mathrm{~K}$ & 0.45 & 0.70 & 1.00 & -0.13 & 0.12 & 0.79 & 0.60 & 0.78 & 0.08 & 0.03 & 0.75 \\
$\mathrm{Ca}$ & 0.01 & -0.05 & -0.13 & 1.00 & 0.76 & -0.02 & 0.38 & 0.30 & -0.24 & 0.93 & 0.01 \\
$\mathrm{Mg}$ & 0.00 & 0.06 & 0.12 & 0.76 & 1.00 & 0.08 & 0.44 & 0.37 & -0.21 & 0.69 & 0.28 \\
$\mathrm{~S}$ & 0.82 & 0.89 & 0.79 & -0.02 & 0.08 & 1.00 & 0.75 & 0.62 & 0.23 & 0.18 & 0.50 \\
$\mathrm{~B}$ & 0.77 & 0.79 & 0.60 & 0.38 & 0.44 & 0.75 & 1.00 & 0.60 & -0.04 & 0.45 & 0.50 \\
$\mathrm{Cu}$ & 0.30 & 0.45 & 0.78 & 0.30 & 0.37 & 0.62 & 0.60 & 1.00 & -0.11 & 0.36 & 0.75 \\
$\mathrm{Fe}$ & 0.18 & 0.25 & 0.08 & -0.24 & -0.21 & 0.23 & -0.04 & -0.11 & 1.00 & -0.08 & 0.02 \\
$\mathrm{Mn}$ & 0.15 & 0.15 & 0.03 & 0.93 & 0.69 & 0.18 & 0.45 & 0.36 & -0.08 & 1.00 & 0.08 \\
$\mathrm{Zn}$ & 0.17 & 0.41 & 0.75 & 0.01 & 0.28 & 0.50 & 0.50 & 0.75 & 0.08 & 0.02 & 1.00 \\
\hline
\end{tabular}

